Rodzhers, K. (2001). Stanovlenye lychnosty. Vzghliad na psykhoterapyiu [Formation of personality. View at psychotherapy]; per. s anhl. M. Khlotnyk. Moskva: Yzd-vo ЭKSMO - Press. 416 s. [In Russian].

Rean, A. (2007). Psykholohyia lychnosty. Sotsyalyzatsyia, povedenye, obshchenye [Psychology of Personality. Socialization, behavior, communication]. Moskva: AST. 407 s. [In Russian].

Bekh, I. (2012). Osobystist u prostori dukhovnoho rozvytku [Personality in the dimension of spiritual development]: navch. posib. Kyiv: Akademvydav. 256 s. [In Ukrainian].

Chepelieva, N. V. (1999). Formuvannia profesiinoi kompetentnosti psykholoha [Formation of professional psychologist competence]. Aktualni problemy psykholohii: naukovi zapysky instytutu psykholohii im. H. S. Kostiuka APN Ukrainy / za red. akademika S. D. Maksymenka. Kyiv: Nika - Tsentr. Vyp. 19. 286 s. [In Ukrainian].

Panok, V., Tytarenko, T., Chepelieva, N. ta in. (2006). Osnovy praktychnoi psykholohii [Basics of practical psychology]: pidruchnyk. 3-tie vyd. Lybid. 536 s. [In Ukrainian].

Radchuk, H. K., Andriichuk, I. P. (2002). Psykholoho-pedahohichni umovy harmonizatsii «Ia-kontseptsii» maibutnikh praktychnykh psykholohiv [Psychological and pedagogical conditions of harmonization «I-concept» of future practical psychologists]: metodychni rekomendatsii dlia vykladachiv VNZ ta praktychnykh psykholohiv osvity. Ternopil. 48 s. [In Ukrainian].

Drach I. I. (2013). Upravlinnia formuvanniam profesiinoi kompetentnosti mahistrantiv pedahohiky vyshchoi shkoly: teoretyko-metodychni zasady [Formation management of professional competence of undergraduates higher school pedagogy: theoretical and methodological principles]: monohrafiia. Kyiv: Dorado-Druk. 456 s. [In Ukrainian].

Дата надходження до редакиї: 30.03.2021 p.
УДК 378.018.46

DOI: 10.37026/2520-6427-2021-106-2-21-28

\author{
Надія ТКАЧУК, \\ кандидат педагогічних наук,доцент \\ кафедри педагогіки та психології \\ Волинського інституту \\ післядипломної педагогічної освіти, \\ м. Луцььк, Украӥна \\ ORCID: 0000-0002-8018-9733 \\ e-mail: nadia.tkachuk4@gmail.com
}

\section{Неля КIHАX,}

кандидат економічних наук, доцент, доиент кафедри педагогіки та психології Волинського інституту післядипломної педагогічної освіти, м. Луцььк, Украӥна

ORCID: 0000-0002-9025-6514

e-mail:nelyakinax@gmail.com

\title{
ПРОФЕСІЙНИЙ СТАНДАРТ ЯК ВЕКТОР МОДЕРНІЗАЦІЇ ПІСЛЯДИПЛОМНОЇ ПЕДАГОГІЧНОЇ ОСВІТИ
}

\begin{abstract}
Анотація. У статті проаналізовано нормативно-правову базу, щуо регламентує створення професійних стандартів; розглянуто окремі підходи та принщипи із зарубіжного досвіду щзодо стандартизащії освіти; визначено сфери застосування професійного стандарту. Зазначено, шуо новий професійний стандарт учителя визначає загальні (громадянська, соиіальна, культурна, лідерська та підприсмницька) і професійні компетентності педагога (мовно-комунікативна, предметно-методична, інформаційно-ицифрова, психологічна, емоиійно-етична, педагогічне партнерство, інклюзивна, здоров'язбережувальна, проєктувальна, прогностична, організаційна, оцінювально-аналітична, інновачійна, рефлексивна, здатність до навчання впродовж життя), щзо є складовими загальної моделі професійної компетентності
\end{abstract}

педагога. Проведено пілотне дослідження щуодо ставлення педагогів до нового професійного стандарту в контексті забезпечення якості підвищення кваліфікації та особистого безперервного навчання. Обтрунтовано ставлення педагогів до нового професійного стандарту в контексті забезпечення якості підвищення кваліфікації та особистого безперервного навчання. Проаналізовано актуальність загальних і професійних компетентностей педагогів у структурі професійного розвитку, визначено пріоритетність трудових функиій у системі особистісного розвитку вчителя; зроблено акиент на важливості врахування нового професійного стандарту вчителя в проєктуванні професійного розвитку педагогів.

Ключові слова: компетентність, підвищення кваліфікаиії, професійний розвиток, стандарт, стандартизація. 


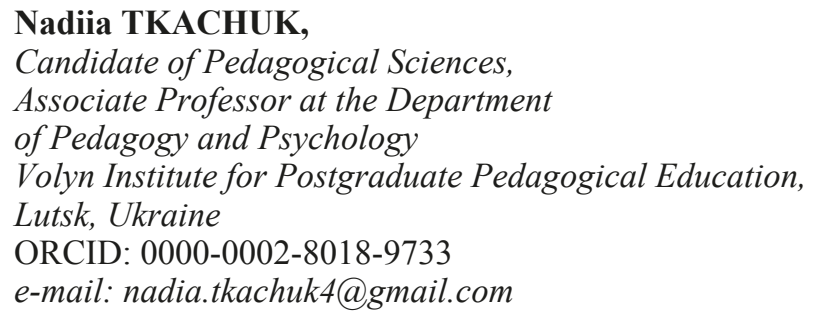

Nelia KINAKH,

Candidate of Economic Sciences,

Associate Professor,

Associate Professor at the Department

of Pedagogy and Psychology

Volyn Institute for Postgraduate Pedagogical Education,

Lutsk, Ukraine

ORCID: 0000-0002-9025-6514

e-mail:nelyakinax@gmail.com

\section{PROFESSIONAL STANDARD AS A VECTOR OF MODERNIZATION OF POSTGRADUATE PEDAGOGICAL EDUCATION}

\begin{abstract}
The article analyzes the regulatory framework governing the creation of professional standards; some approaches and principles from foreign experience in standardization of education are considered; the spheres of application of the professional standard are defined; it is noted that the new professional standard of a teacher defines general (civic, social, cultural, leadership and entrepreneurial) and professional competencies of a teacher (linguistic-communicative, subject-methodical, information-digital, psychological, emotional-ethical, pedagogical partnership, inclusive, health). conservation, design, prognostic, organizational, evaluative-analytical, innovative, reflective, ability to learn throughout life), which are part of the general model of professional competence of the teacher; a pilot study of teachers attitudes to the new professional standard in the context of quality assurance of in-service training and personal lifelong learning; the attitude of teachers to the new professional standard in the context of quality assurance of in-service training and personal lifelong learning is substantiated; the relevance of general and professional competencies of teachers in the structure of professional development is assessed, the priority of labor functions in the system of personal development of a teacher is determined; emphasis is placed on the importance of taking into account the new professional standard of teachers in designing the professional development of teachers.

As a result of our scientific research, it has been determined that professional standards are a certain marker and reference point in ensuring high-quality modern personal and professional development of teachers, a measure of updating the system of professional development of teachers. Therefore, it is important that teachers develop intrinsic motivation and the need for systematic design of individual educational trajectory with a focus on the formation and development of the necessary professional competencies.
\end{abstract}

Key words: competence, advanced training, professional development, standard, standardization.

Постановка проблеми. Важливою ознакою інтеграції вітчизняної освіти в європейський освітній простір є перехід на освітні стандарти, що грунтуються на навчальних результатах, виражених у компетентностях. Нинішні вимоги щодо обов'язкових результатів навчання здобувачів загальної середньої освіти окреслені у державних стандартах загальної середньої освіти відповідного рівня. Зокрема у Державному стандарті базової середньої освіти визначено, що результатом освіти на цьому етапі є формування компетентностей, необхідних для соціалізації та громадянської активності, свідомого вибору подальшого життєвого шляху та самореалізації, продовження навчання на рівні профільної освіти або здобуття професії, виховання відповідального, шанобливого ставлення до родини, суспільства, довкілля, національних та культурних цінностей українського народу (Державний стандарт базової середньої освіти, 2020). Успіх формування такої особистості, рівень їі компетентностей залежить від багатьох чинників, передусім від рівня професійної компетентності педагогів.

На сьогодні об' єктивним фактором, що створює певні виклики, встановлює рамки професійного розвитку та підготовки вчителів $є$ схвалення нового професійного стандарту за професіями «Вчитель початкових класів закладу загальної середньої освіти», «Вчитель закладу загальної середньої освіти», «Вчитель 3 початкової освіти (з дипломом молодшого спеціаліста)» (2020).

Проблеми професійного розвитку тривалий час викликають глибокий інтерес у дослідників. Існує велика кількість наукових праць із цієї теми. Оприлюднені на шпальтах провідних вітчизняних та зарубіжних видань педагогічні розвідки із проблем якості 
сучасної вищої та професійної освіти засвідчують, що підготовка працівників за професійними стандартами $€$ предметом наукового обгрунтування.

Проте ці роботи не забезпечують повного розуміння багаторівневого динамічного явища професійного розвитку вчителів в умовах реформи, спонукають до постановки нових питань, наукових проблем, пошуків змісту та форм у контексті професійного стандарту вчителя.

Аналіз наукових досліджень і публікацій. Вирішенню проблеми професійного розвитку в контексті сучасних умов присвячували дослідження такі вчені: І. Бех, В. Моляко, Н. Ничкало, О. Пєхота, Л. Пуховська, О. Савченко, В. Сєриков, О. Сухомлинська, В. Хайруліна, I. Якиманська та ін. Важливе значення мають наукові праці щодо структури професійної компетентності та формування особистості вчителя як суб'єкта педагогічної діяльності (І. Бех, Н. Борисенко, В. Свдокимов, Н. Кузьміна, А. Маркова, Л. Мітіна, О. Пєхота, В. Серіков, В. Сластьонін та ін.).

Вивченням новітніх тенденцій розвитку професійних стандартів і кваліфікацій у країнах із високорозвинутою економікою займалися Л. Локшина, Л. Лук'янова, Н. Ничкало, А. Ворначев, С. Мельник, Ю. Кравець, Л. Пуховська та ін.

Однак питання професійного розвитку, які постають перед сучасною післядипломною освітою, з огляду на затверджений професійний стандарт потребують окремого аналізу.

Мета статті полягає у визначенні шляхів розвитку системи післядипломної педагогічної освіти в контексті нового професійного стандарту вчителя.

Виклад основного матеріалу дослідження. Актуальність дослідження зумовлена сучасними змінами парадигм суспільного розвитку, новизною особистісних та соціальних вимог до системи професійної освіти педагога та його готовності до професійного розвитку в системі неперервної освіти.

У правовому полі кадрового забезпечення вітчизняне законодавство останніх років вводить термін «професійний стандарт». Визначення цього поняття знаходимо у Законі України «Про професійно-технічну освіту» (ст. 32), який пропонує розглядати професійний стандарт як сукупність державних вимог до змісту професійної (професійно-технічної) освіти, рівня кваліфікації випускника закладу професійної (професійно-технічної) освіти та освітнього рівня вступників (Закон України «Про професійну (професійно-технічну) освіту», 1998).

У Законі України «Про вищу освіту» (ст. 10) стандарт розглядається як сукупність вимог до освітніх програм вищої освіти, які є спільними для всіх освітніх програм у межах певного рівня вищої освіти та спеціальності та використовуються для визначення та оцінювання якості вищої освіти й результатів освітньої діяльності закладів вищої освіти (наукових установ), результатів навчання за відповідними спеціальностями (Закон України «Про вищу освіту», 2014). У Законі України «Про вищу освіту» також зазначається, що: якість вищої освіти полягає у відповідності умов провадження освітньої діяльності та результатів навчання вимогам законодавства та стандартам вищої освіти, професійним та/або міжнародним стандартам (за наявності), а також потребам зацікавлених сторін і суспільства, що забезпечується шляхом здійснення процедур внутрішнього та зовнішнього забезпечення якості (ст. 1); освітні програми, що передбачають присвоєння професійних кваліфікацій, мають забезпечувати виконання вимог відповідних професійних стандартів (за наявності), якщо інше не передбачено законодавством (ст. 8) (2014). У Законі України «Про освіту» узагальнено, що стандарт освіти визначає: вимоги до обов'язкових компетентностей та результатів навчання здобувача освіти відповідного рівня; загальний обсяг навчального навантаження здобувачів освіти; інші складники, передбачені спеціальними законами (ст. 32). Крім того, він є основою для розроблення освітньої програми відповідного рівня (ст. 33) (Закон України «Про освіту», 2017).

Дослідники зарубіжного досвіду питань стандартизації розглядають професійні стандарти як документи, що встановлюють вимоги до знань, умінь, компетенцій, досвіду, системи цінностей та особистісних якостей, необхідних для виконання певної роботи чи професійних обов'язків, як один з інструментів, що допомагає створити стійку й ефективну взаємодію сфери праці та освіти, забезпечити раціональне використання людських ресурсів, а також сприяти стійкому розвитку суспільства (Пуховська, 2014, с. 126).

Розвиток системи професійної вищої освіти у країнах із високорозвинутою економікою засвідчує, що істотними ознаками вдосконалення якості насамперед $є$ : стандартизація змісту професій; застосування сучасних підходів до розроблення професійних стандартів, що грунтуються на компетенціях; відкритість кваліфікацій для формального, неформального та інформального навчання тощо (Пуховська, 2014).

Вітчизняні дослідники вказують, що в основу розробки стандартів у європейських країнах покладено три аспекти, які застосовуються різною мірою: професійні стандарти визначають «основні професії», описуючи фахові завдання й операції, а також компетенції, типові для цієї професії («Що фахівець повинен уміти виконувати на робочому місці?»); освітні стандарти визначають очікувані результати освітнього процесу, програму навчання у сенсі змісту, навчальних завдань і планів, а також методів й умов навчання («Чого учень повинен навчитися, щоб у майбутньому бути ефективним працівником?»); оцінні стандарти визначають об'єкт оцінки, критерії успішності, методи оцінювання, стандарти, а також склад комісії, яка надає відповідну кваліфікацію («Як ми пересвідчимося, що майбутній фахівець отримав потрібні знання й уміння для виконання роботи?») (Пуховська, 2014, с. 47). Вчені зауважують, що розроблення, вдосконалення і впровадження у практику професійних стандартів розвивається в світі за кількома напрямами. По-перше, відбувається рух від локальних галузевих систем стандартів до формування загальнонаціональних систем. По-друге, розробляються нові підходи й методи формування і використання професійних стандартів. Вони починають активно застосовуватися як у сфері праці, забезпечуючи кероване кар'єрне зростання та професійний розвиток, так і у сфері освіти, де створюють основу для розробки програм професійної підготовки й ефективніших методів оцінювання та 
атестації результатів професійного навчання. По-третє, збільшується коло «користувачів» професійних стандартів, що охоплює не лише співробітників кадрових служб чи служб, котрі відповідають за підготовку персоналу на виробництві, а й роботодавців та працівників, які здобувають професійну освіту різного рівня, викладачів і керівників навчальних закладів. По-четверте, розширюється обмін досвідом щодо проблем формування використання професійних стандартів (Пуховська, 2014, с. 126-127). Спільними принципами побудови професійних стандартів $є$ :

- основа стандартизації - професійна діяльність, результати якої мають вимірюватися;

- порівнюваність у рамках подібних / різних професій (наприклад, порівнюваність структури тощо);

- проста структура, чіткість і ясність; одиниці професійного стандарту складають основу кваліфікаційних стандартів (Пуховська, 2014, с. 87).

В Україні, з огляду на міжнародний досвід, були прийняті зазначені вище законодавчі норми, а також у 2017-2018 роках нормативні акти, що роз'яснюють порядок формування та затвердження професійних стандартів, методику їхнього розроблення.

Загальні вимоги до процедури розроблення, громадського обговорення, затвердження, введення в дію та перегляду професійних стандартів унормовано у Порядку розроблення та затвердження професійних стандартів, затвердженого постановою КМУ від 31.05.2017 р. № 373.

Для забезпечення єдиного підходу, дотримання об'єктивності під час розроблення професійних стандартів та забезпечення якості проведення їх перевірки, 3 метою надання методичної допомоги укладачам та іншим зацікавленим суб'єктам було розроблено Методику розроблення професійних стандартів, затверджену наказом Міністерства соціальної політики України від 22.01.2018 р. № 74.

У цьому документі зазначено, що Професійні стандарти використовуються у сфері освіти для:

- розроблення освітніх програм / стандартів та навчально-методичних матеріалів для всіх форм і видів освіти, навчання працівників на виробництві, підготовки педагогічних / науково-педагогічних працівників;

- розроблення стандартів оцінювання результатів навчання, присвоєння здобувачам професійних кваліфікацій, оцінювання відповідності отриманих професійних кваліфікацій працівників, випускників закладів освіти;

- проведення процедур підтвердження результатів неформального професійного навчання осіб;

- формування єдиних критеріїв оцінювання компетентностей здобувачів професійних кваліфікацій, незалежно від шляхів (формальна чи неформальна освіта, неформальне чи інформальне (спонтанне) навчання) їх отримання;

- професійної орієнтації населення, в тому числі учнів і студентів закладів освіти, працівників та безробітних (Методика розроблення професійних стандартів, 2018).

Новий професійний стандарт учителя за трьома професіями, зокрема «Вчитель початкових класів закладу загальної середньої освіти», «Вчитель закладу загальної середньої освіти», «Вчитель 3 початкової освіти (3 дипломом молодшого спеціаліста)» побудований відповідно до цих рекомендацій, а також відображає загальносвітові тенденції щодо структури та принципів стандартизації професійної освіти в європейському освітньому просторі (Професійний стандарт за професіями «Вчитель початкових класів закладу загальної середньої освіти», «Вчитель закладу загальної середньої освіти», «Вчитель 3 початкової освіти (з дипломом молодшого спеціаліста)», 2020).

Документ внесено до Реєстру професійних стандартів (наказ Мінекономіки від 23.12.2020 р. № 2736), що забезпечує чинність його використання у таких сферах:

- підготовка майбутніх учителів: розробка відповідних програм бакалавра та магістра, наповнення дисциплін згідно з новим профстандартом педагога;

- акредитація освітніх програм підготовки вчителів;

- підвищення кваліфікації педагога: використання при розробленні програм підвищення кваліфікацій визначених компетентностей учителя; орієнтування для підтвердження педагогічною радою результатів неформального та інформального навчання педагогів;

- підвищення кваліфікації працівників центрів професійного розвитку та ІППО;

- самооцінювання педагога: створення методичних матеріалів, анкет та рекомендації для педагогів щодо оцінки власної діяльності;

- розроблення посадових інструкцій та умов роботи, створення умов для рухової активності та здорового харчування педагогічних працівників;

- атестація вчителів та сертифікація вчителів (Головіна, 2020; Головіна, 2021).

Важливо зауважити, що попри вказані сфери застосування розробниками зроблено акцент на необхідності розвивального (містить визначення компетентностей, що вказують на результативність, підкреслює цінності, мету та ролі в навчанні), а не статичного стандарту (орієнтований на вимірювання, моніторинг, порівняння та регулювання професійної діяльності). Укладачі підкреслюють, що завданням було запропонувати стандарт, який би давав змогу вчителеві бачити свою траєкторію розвитку й розуміння - як вибудовувати кар'єру на основі рефлексії своєї професійної діяльності (Головіна, 2021). За словами експертки експертної групи з питань нормативно-правового забезпечення директорату шкільної освіти Міністерства освіти і науки України Н. Сторчак, професійний стандарт - це не документ, який лише констатує вимоги до вчителя для прийняття на роботу чи перевірки відповідності займаній посаді (наявність цього вимагає трудове законодавство), а й має орієнтири для професійного розвитку (Головіна, 2021).

Отже, розробка та затвердження у грудні 2020 року професійного стандарту вчителя створює умови для обгрунтування нового змісту підвищення кваліфікації та особистісно-професійного розвитку педагогів початкових класів, педагогів закладів загальної середньої освіти на наступні п'ять років у сфері післядипломної педагогічної освіти.

Документ визначає загальні (громадянська, соціальна, культурна, лідерська та підприємницька) і професійні компетентності вчителя (мовно-комунікативна, предметно-методична, інформаційно-цифрова, 
психологічна, емоційно-етична, педагогічне партнерство, інклюзивна, здоров'язбережувальна, проєктувальна, прогностична, організаційна, оцінювально-аналітична, інноваційна, рефлексивна, здатність до навчання впродовж життя), які є складовими загальної моделі професійної компетентності педагога (Професійний стандарт за професіями «Вчитель початкових класів закладу загальної середньої освіти», «Вчитель закладу загальної середньої освіти», «Вчитель з початкової освіти (з дипломом молодшого спеціаліста)», 2020).

Автори вказують, що до переліку компетентностей внесені такі, що пов'язані зі змістом навчального предмета й методики викладання, але поряд із ними $є$ й ті компетентності, без яких сучасний учитель не може бути успішним, здатним до інновацій та педагогіки партнерства (Головіна, 2020; Головіна, 2021).

Згідно з українським законодавством невід' $€$ ною частиною стандарту для кожної професії є трудові функції. Зокрема, у професійному стандарті вчителя це: «навчання учнів предметів (інтегрованих курсів)»; «партнерська взаємодія з учасниками освітнього процесу»; «участь в організації безпечного та здорового освітнього середовища»; «управління освітнім процесом»; «безперервний професійний розвиток».

У межах кожної трудової функції вказано компетентності, якими має володіти вчитель. Стандарт кодифікований, що забезпечує прозорість опису трудової функції через предмети та засоби праці, професійні компетентності, знання, вміння та навички. Л. Гриневич вказує на важливість використання кодифікації при укладанні освітніх програм підвищення кваліфікації, що забезпечить чітке повідомлення вчителю, на розвиток якої компетентності, яких здатностей, знань та вмінь спрямовані навчальні курси (Головіна, 2020). Саме такий підхід побудови змісту робить Стандарт прикладним документом у плануванні професійного розвитку за індивідуальною освітньою траєкторією.

Експерти з питань стандартизації зазначають, що світова практика вказує на проблему використання стандартів практикуючими педагогами в проєктуванні професійного розвитку. Взявши до уваги таке спостереження, нами було зроблено пілотне дослідження щодо ставлення педагогів до нового професійного стандарту в контексті забезпечення якості підвищення кваліфікації та особистого безперервного навчання.

В опитуванні взяли участь слухачі Волинського інституту післядипломної педагогічної освіти в період лютого-березня 2021 року. Всього було опитано 222 респонденти, 3 них 56,3\% - педагоги міських шкіл, $34,2 \%$ - сільських шкіл та 9,5\% - селищ міського типу. Серед опитуваних були вчителі біології, англійської мови, початкових класів, математики.

На запитання «Чи ознайомлені Ви з професійним стандартом учителя» ствердно відповіли 98,2\% опитаних, з яких 64,9\% респондентів однозначно підтвердили необхідність використання стандарту у своїй професійній діяльності, а 33,8\% - обрали відповідь «скоріше так».

Щодо можливих сфер використання професійного стандарту - найвищий показник отримав варіант відповіді «самооцінювання власної професійної діяльності» та «визначення пріоритетів при проєктуванні індивідуальної траєкторії професійного розвитку» (див. рис. 1).

Інформативним $€$ отриманий результат щодо важливості розвитку загальних та професійних компетентностей (див. рис. 2, 3).

Так, серед загальних компетентностей у пріоритеті майбутнього розвитку є соціальна $(78,8 \%)$ та громадянська (164\%); серед професійних - мовно-комунікативна $(65,3 \%)$, предметно-методична $(60,8 \%)$, здоров'язбережувальна (59,9\%), здатність до навчання впродовж життя (59,5\%).

Відповіді педагогів на запитання «Оберіть $з$ перелічених трудових функцій три пріоритетні для Вас особисто» визначили, що найважливішими функціями $є$ : партнерська взаємодія з учасниками освітнього процесу; участь в організації безпечного та здорового освітнього середовища; безперервний професійний розвиток (див. рис. 4).

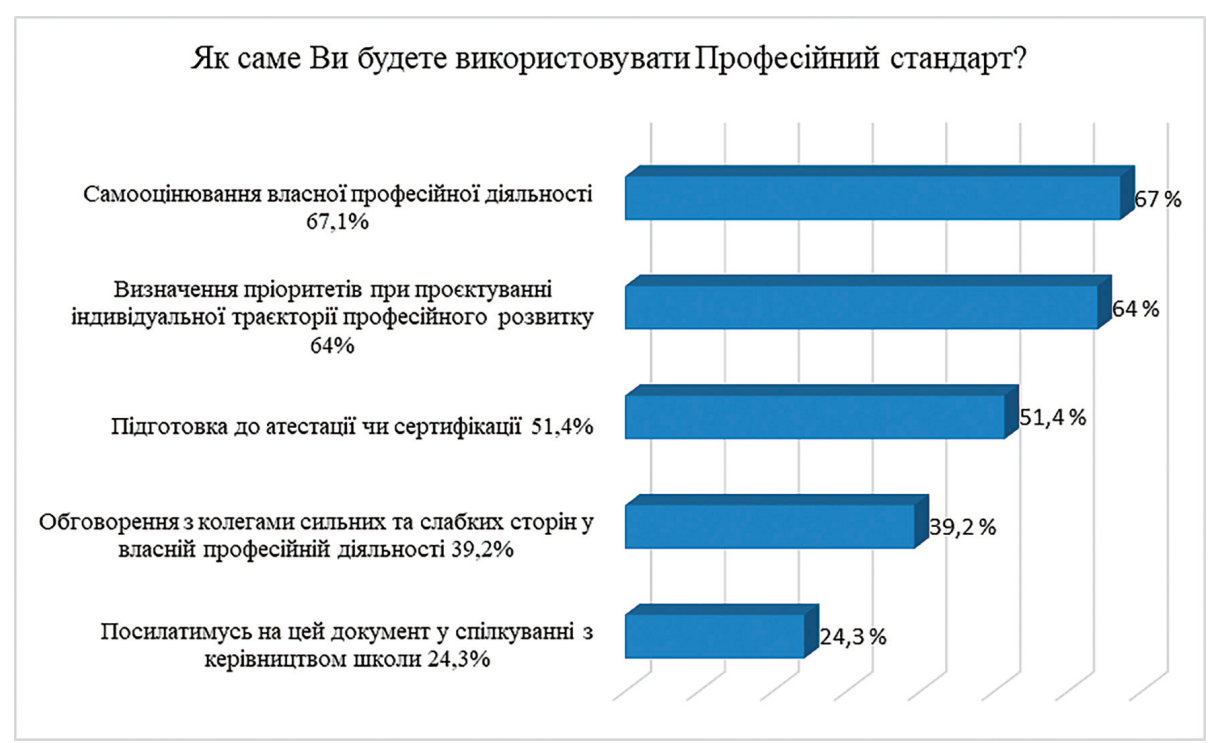

Рис. 1. Ставлення педагогів до нового професійного стандарту в контексті забезпечення якості підвищення кваліфікації та особистого безперервного навчання 


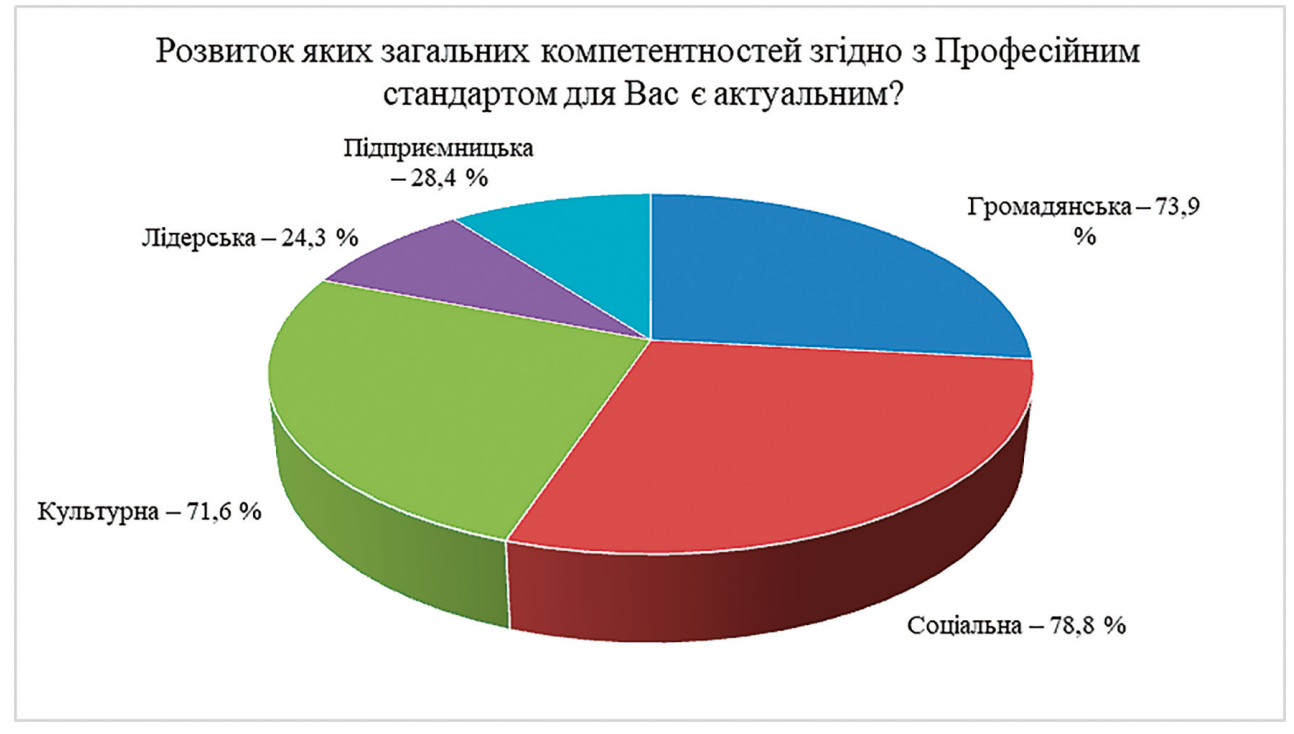

Рис. 2. Структура загальних компетентностей професійного стандарту

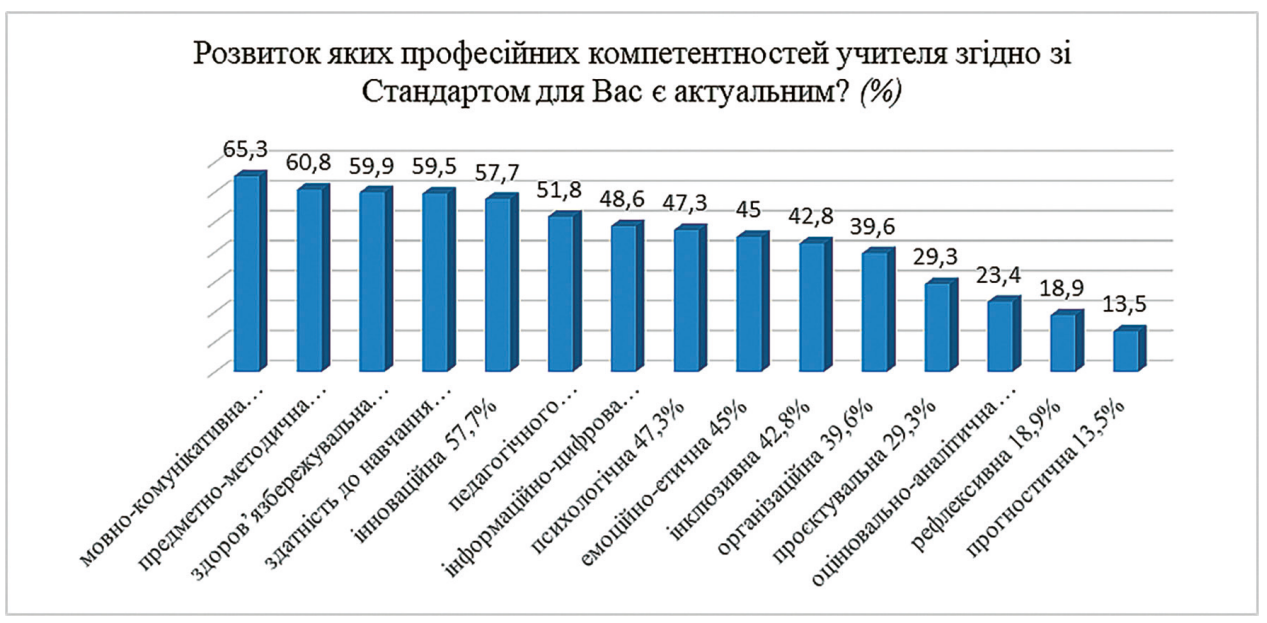

Рис. 3. Структура професійних компетентностей учителя згідно зі стандартом професійного розвитку

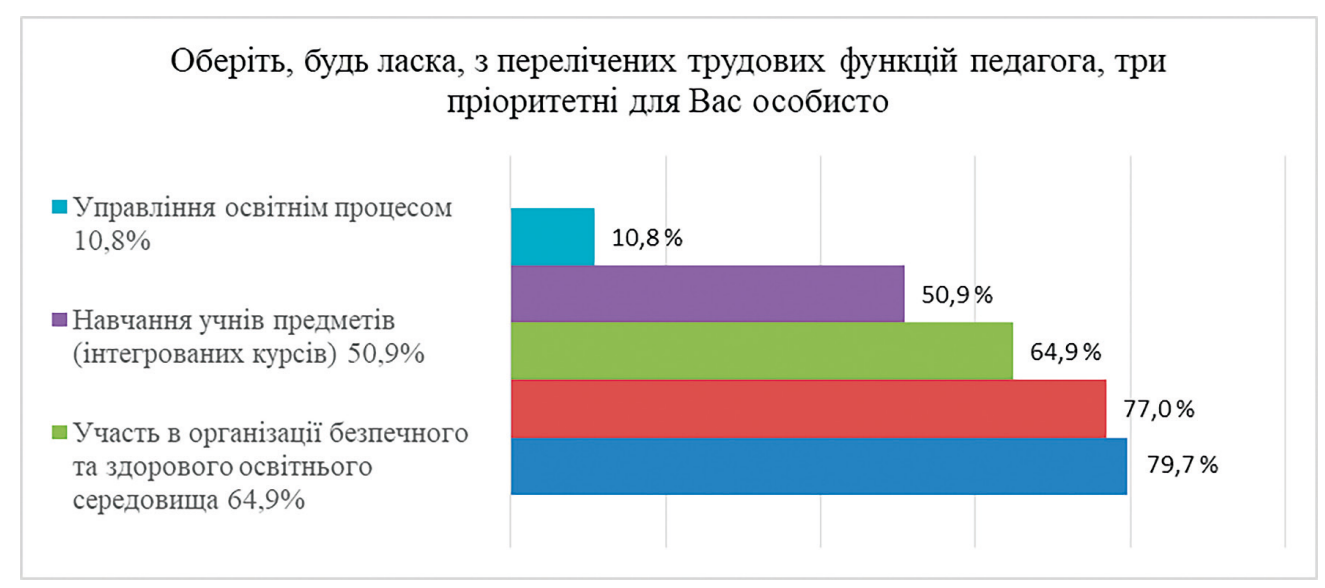

Рис. 4. Пріоритетність трудових функиій педагога в системі професійного розвитку 
Порівняння цих результатів із відповідями на запитання щодо розвитку професійних компетентностей наштовхує на певні роздуми, породжує перестороги щодо глибокого та усвідомленого опрацювання учасниками опитування змісту стандарту. Адже функція «партнерська взаємодія з учасниками освітнього процесу» розкривається через психологічну, емоційно-етичну компетентність та компетентність педагогічного партнерства. Функція «участь в організації безпечного та здорового освітнього середовища» містить інклюзивну та проєктувальну компетентність. Однак ці компетентності не були визначені як пріоритетні в особистому професійному зростанні.

Результати проведеного опитування ставлять перед ІППО завдання якнайширшого обговорення змісту стандарту та розробки відповідних освітніх програм. Укладачі та експерти вказують на важливості культивування у вчительському середовищі розуміння стандарту, виходячи з основних понять - «професія» i «стандарт». Стандарт - як мірило якості й показник вимог, професія - як служіння суспільству, відчуття обов'язку робити свою справу добре (Головіна, 2020). Можемо підсумувати, що вирішальною умовою якісного результативного освітнього процесу є особа вчителя, його позиція щодо власного професійного розвитку в контексті викликів та завдань сучасної освіти.

Висновки. В сучасному освітньому просторі беззаперечними цінностями визнано саморозвиток, самоосвіту, самопроєктування, самореалізацію та самоактуалізацію особистості, які стали підгрунтям до запровадження нового підходу в системі професійного розвитку педагогів. Прийняття нового професійного стандарту є певним викликом як для педагогів, так і для післядипломної педагогічної освіти. $Є$ потреба в чітких орієнтирах щодо забезпечення відповідного змісту індивідуальної освітньої траєкторії, в системності та створенні структурно-змістових умов відкритого освітнього середовища післядипломної освіти для проєктування розвитку з урахуванням сучасного розуміння структури професійної компетентності.

Можемо підсумувати, що професійні стандарти є певним маркером та орієнтиром у забезпеченні якісного сучасного особистісно-професійного розвитку педагогів, мірилом оновлення системи підвищення кваліфікації педагогів. Важливо, щоб учителі розвивали внутрішню мотивацію та потребу до системного проєктування індивідуальної освітньої траєкторії з орієнтацією на формування й розвиток необхідних професійних компетентностей відповідно до професійного стандарту.

Перспективи подальших досліджень будуть стосуватися питань проєктування освітнього середовища післядипломної освіти та вивчення умов реалізації права на вибір підвищення кваліфікації та якісну освіту впродовж життя.

\section{СПИСОК ВИКОРИСТАНОЇ ЛІТЕРАТУРИ}

Державний стандарт базової середньої освіти. URL: https://www.kmu.gov.ua/npas/pro-deyaki-pitannyaderzhavnih-standartiv-povnoyi-zagalnoyi-serednoyiosviti-i300920-898 (дата звернення: 14. 04. 2021).

Про професійну (професійно-технічну) освіту: Закон України. Редакція від 01.01.2021. Відомості
Верховної Ради. 1998. №32. 215 с.

Про вищу освіту: Закон України від 01.07.2014 p. №1556-VII. Відомості Верховної Ради. 2014. №37-38. Ст. 2004.

Про освіту: Закон України від 05.09.2017 р. № 2145-VIII. Відомості Верховної Ради. 2017. № 38-39. $380 \mathrm{c}$.

Методика розроблення професійних стандартів / М-во соціальної політики України. URL : https://zakon. rada.gov.ua (дата звернення: 07.04.2021).

Професійний стандарт за професіями «Вчитель початкових класів закладу загальної середньої освіти», «Вчитель закладу загальної середньої освіти», «Вчитель 3 початкової освіти (з дипломом молодшого спеціаліста)» / М-во розвитку економіки, торгівлі та сільського господарства України. URL: https://nus.org. ua/wp-content/uploads/2020/12/Nakaz_2736.pdf (дата звернення: 23.03.2021).

Пуховська, Л., Ворначев, А., Мельник, С., Кравець, Ю. (2014). Професійні стандарти і кваліфікації у країнах з високорозвинутою економікою: монографія. Київ. 176 с.

Головіна, О. (2020). Професійний стандарт вчителя - міжнародний досвід. Нова украӥнська школа. URL: https://nus.org.ua/articles/profesijnyj-standart-vchytelyamizhnarodnyj-dosvid/ (дата звернення: 03.04.2021).

Головіна, О. (2020). Професійний стандарт вчителя. Лілія Гриневич про його важливість і необхідність. Нова українська школа. URL: https://nus.org.ua/articles/ profesijnyj-standart-vchytelya-liliya-grynevych-pro-jogovazhlyvist-i-neobhidnist/(дата звернення: 03.04.2021).

Головіна, О. (2021). Як будуть впроваджувати новий стандарт учителя? Нова українська школа. URL: https://nus.org.ua/articles/yak-budut-vprovadzhuvatyprofesijnyj-standart-uchytelya/ (дата звернення: 03.04.2021).

\section{REFERENCES}

Derzhavnyi standart bazovoi serednoi osvity [State standard of basic secondary education]. URL: https://www. kmu.gov.ua/npas/pro-deyaki-pitannya-derzhavnih-standartiv-povnoyi-zagalnoyi-serednoyi-osviti-i300920-898 (data zvernennia: 14. 04. 2021). [in Ukrainian].

Pro profesiinu (profesiino-tekhnichnu) osvitu: Zakon Ukrainy [On a professional (vocational) education: Law of Ukraine]. Redaktsiia vid 01.01.2021. Vidomosti Verkhovnoi Rady. 1998. №32. 215 s. [in Ukrainian].

Pro vyshchu osvitu: Zakon Ukrainy vid 01.07.2014 r. №1556-VII. Vidomosti Verkhovnoi Rady. 2014. № 37-38. St. 2004. [in Ukrainian].

Pro osvitu: Zakon Ukrainy vid 05.09.2017 r. № 2145VIII [On higher education: Law of Ukraine of 01.07.2014 p. №1556-VII]. Vidomosti Verkhovnoi Rady. 2017. № 38-39. 380 s. [in Ukrainian].

Metodyka rozroblennia profesiinykh standartiv Methods of developing professional standards] / M-vo sotsialnoi polityky Ukrainy. URL: https://zakon.rada.gov.ua (data zvernennia: 07.04.2021). [in Ukrainian].

Profesiinyi standart za profesiiamy «Vchytel pochatkovykh klasiv zakladu zahalnoi serednoi osvity», «Vchytel zakladu zahalnoi serednoi osvity», "Vchytel z pochatkovoi osvity (z dyplomom molodshoho spetsialista)» 
[Professional standard by professions «Primary school teacher of general secondary education», «Teacher of general secondary education», «Primary teacher (with a diploma of junior specialist)»] / M-vo rozvytku ekonomiky, torhivli ta silskoho hospodarstva Ukrainy. URL: https:// nus.org.ua/wp-content/uploads/2020/12/Nakaz_2736.pdf (data zvernennia: 23.03.2021). [in Ukrainian].

Pukhovska, L., Vornachev, A., Melnyk, S., Kravets, Yu. (2014). Profesiini standarty i kvalifikatsii u krainakh z vysokorozvynutoiu ekonomikoiu [Professional standards and qualifications in countries with highly developed economies]: monohrafiia. Kyiv. 176 s. [in Ukrainian].

Holovina, O. (2020). Profesiinyi standart vchytelia - mizhnarodnyi dosvid [Professional standards and qualifications in countries with highly developed economics]. Nova ukrainska shkola. URL: https://nus.org.ua/articles/ profesijnyj-standart-vchytelya-mizhnarodnyj-dosvid/ (data zvernennia: 03.04.2021). [in Ukrainian].

Holovina, O. (2020). Profesiinyi standart vchytelia. Liliia Hrynevych pro yoho vazhlyvist i neobkhidnist [Teacher's professional standard. Lilia Hrynevych about its importance and necessity]. Nova ukrainska shkola. URL: https://nus.org.ua/articles/profesijnyj-standart-vchytelya-liliya-grynevych-pro-jogo-vazhlyvist-i-neobhidnist/ (data zvernennia: 03.04.2021). [in Ukrainian].

Holovina, O. (2021). Yak budut vprovadzhuvaty novyi standart uchytelia? [How will the new teacher standard be implemented?]. Nova ukrainska shkola. URL: https://nus.org.ua/articles/yak-budut-vprovadzhuvaty-profesijnyj-standart-uchytelya/ (data zvernennia: 03.04.2021). [in Ukrainian].

Дата надходження до редакиії: 20.04.2021 p.
УДК 37.091.33: 373.5

DOI: 10.37026/2520-6427-2021-106-2-28-32
Iryna UDOVYCHENKO,

Doctor of Pedagogical Sciences, Associate Professor, Vice-rector, Sumy Regional Institute of Postgraduate Pedagogical Education, Sumy, Ukraine ORCID: 0000-0002-1980-5402

e-mail:hafran@ukr.net

\section{ACTUALITY OF INTEGRATION PROCESS OF PHILOLOGY AND EDUCATIONAL KNOWLEDGE IN THE SUBJECTS OF UNIVERSAL EDUCATIONAL INSTITUTIONS (ON THE EXAMPLE OF UKRAINE)}

\begin{abstract}
The article deals with the relevance of integration of natural, philology knowledge at geography lessons, which is determined by the current level of development of science and requirements for the education level of school graduates. Attention is focused on the importance of intersubjective connections in school education at current stage of education reform.

Relevance of integration of natural, philology knowledge in geography lessons; development of cross-curricular links in school education, which is conditioned by the current level of development of science and the requirements for the level of education of graduates of general secondary education. The modern teacher needs not so much to give a great deal of information about a topic, but to teach students to understand it, to find additional data through cross-curricular links, and even more to be able to use it and put it into practice. The integration of scientific knowledge places new demands on teachers as professionals. That's why the role of human knowledge in the field, which is related to the specialty of sciences and the ability to comprehensively apply them in solving various
\end{abstract}

educational and methodical problems, is increasing. Practically oriented, integrated approaches are used to make the teaching interesting, comprehensive, which allows the use of cross-curricular links, generalizations for the purpose of better learning of the educational material by the students.

Psychological and pedagogical terms of designing and implementing the content of training, principles of its design, the specificity of the formation of the system of educational knowledge and the structure of scientific and methodological knowledge in geography, taking into account age psychological characteristics of senior students, are presented. On the basis of concretization and logical unity of philosophical and cultural, psychological and pedagogical factors, organizational, methodical aspects and pedagogical terms of studying geography of senior students of senior profile high school in the context of the requirements for the new Ukrainian school are substantiated.

Key words: intersubjective communications, integration of scientific knowledge, binary lessons, geography, establishment of universal middle education. 